RESEARCH ARTICLE

\title{
Special Autonomy of Yogyakarta in the Context of Local Autonomy \\ Law
}

\author{
Muhamad Abdullah Sidiq \\ Lingkar Masyarakat Otonomi Daerah \\ Jl Kaliurang Km 7, Yogyakarta, INDONESIA \\ 四abdulahmuhamad133@gmail.com
}

\section{a OPEN ACCESS}

Citation: Sidiq, M. A. (2021).

Special Autonomy of

Yogyakarta in the Context of

Local Autonomy Law. Law

Research Review

Quarterly, 7(4), 515-524.

https://doi.org/10.15294/Irrq.v

7i4.48191

Submitted : June 9, 2021

Revised : October 12, 2021

Accepted : November 1, 2021

(C) The Author(s)

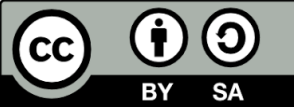

This work is licensed under a Creative Commons Attribution-ShareAlike 4.0 International License. All writings published in this journal are personal views of the authors and do not represent the views of this journal and the author's affiliated institutions.

\section{ISSN 2716-3415}

Law Research Review Quarterly published by Faculty of Law, Universitas Negeri Semarang, Indonesia. Published quarterly on February, May, August, and November.

\section{Abstract}

Local government is the authority of the autonomous regions to organize and manage the interests of local people according to their own initiative based on community aspirations in accordance with the laws and regulations. In response to the demands of government reform quite quickly, it has undertaken a sufficiently fundamental breakthrough of the various laws in the political field from the centralist-authoritarian to the autonomous-democratic. After successfully compiling the three laws on the political field that became the basis of the election in 1999 the government immediately followed him with a new law in the field of special politics on power relations between the central and local, namely Law no. 22 of 1999 on Regional Government and Law No. 25 of 1999 on Financial Relations between Central and Regional. The formation of regions is basically intended to improve public services in order to accelerate the realization of community welfare as well as political education at the local level. Considerations and other conditions that enable the area to organize and realize the purpose of the establishment of the region and the granting of regional autonomy. The Government may designate special areas in the autonomous regions to carry out specific government functions that are specific to national and / or national-scale interests "special" for the interests and benefit of Indonesia. One of these special autonomous regions is the Special Region of Yogyakarta that has been recognized special autonomous region in Law No.13 of 2012 on the privilege of Yogyakarta. In this paper will be much discussed about, the specialty of Yogyakarta 
starting from the history of Yogyakarta, the legislation that regulates, the positive and negative impact of the system of special autonomous regions, the development of Yogyakarta area and other additional discussion of the author.

Keywords: Local Autonomy; Local Government; Special Region

\section{INTRODUCTION}

Regional autonomy is the authority of the autonomous regions to organize and manage the interests of local people according to their own initiative based on community aspirations in accordance with the laws and regulations. In response to the demands of government reform quite quickly, it has undertaken a sufficiently fundamental breakthrough of the various laws in the political field from the centralist-authoritarian to the autonomous-democratic. After successfully compiling the three laws on the political field that became the basis of the election in 1999 the government immediately followed him with a new law in the field of special politics on power relations between the central and local, namely Law no. 22 of 1999 on Regional Government and Law No. 25 of 1999 on Financial Relations between Central and Regional.

The formation of regions is basically intended to improve public services in order to accelerate the realization of community welfare as well as political education at the local level. Considerations and other conditions that enable the area to organize and realize the purpose of the establishment of the region and the granting of regional autonomy. The Government may designate special areas in the autonomous regions to carry out specific government functions that are specific to national and / or national-scale interests "special" for the interests and benefit of Indonesia. One of these special autonomous regions is the Special Region of Yogyakarta that has been recognized special 
autonomous region in Law No.13 of 2012 on the privilege of Yogyakarta.

In this paper will be much discussed about, the specialty of Yogyakarta starting from the history of Yogyakarta, the legislation that regulates, the positive and negative impact of the system of special autonomous regions, the development of Yogyakarta area and other additional discussion of the author. For problem restrictions, the focus on the issues to be addressed are starting from Special autonomy addresses the Special Territory of Yogyakarta, Government and territory of Yogyakarta Special Region, Privileges of Yogyakarta Special Region, Problems arising in region. Furthermore, formulation of the problem to be discussed are (1) how is history from Yogyakarta? (2) what is the process of establishing a special autonomous region by Yogyakarta? (3) what are the positive and negative effects of special autonomy given to Yogyakarta, and (4) how is the development of the current Yogyakarta government?

\section{RESULT AND DISCUSSION}

\section{A. History of Yogyakarta Special Region: Society and Law Context}

Yogyakarta Special Region (DIY) is the second oldest province in Indonesia after East Java, formed by the state government of Indonesia. The province also has special status or special autonomy. This status is a legacy from the time before independence According to Babad Gianti, Yogyakarta or Ngayogyakarta (Javanese) is the name given Paku Buwono II (king of Mataram year 1719-1727) as a substitute name of Gartitawati guesthouse. Yogyakarta means Yogya yang kerta, prosperous Yogya, while Ngayogyakarta Hadiningrat means prosperous Yogya and most importantly. Another source said, the name of Yogyakarta is taken from the name (mother) Sanskrit Ayodhya city in the epic Ramayana. In its daily use, Yogyakarta is commonly spoken Jogja (karta) or 
Ngayogyakarta (Javanese language). Prior to independence Indonesia, Yogyakarta already has a tradition of government because Yogyakarta is Kasultanan, including there is also Duchy of Pakualam. The region that has its origins with its own government, in the Dutch colonial era called Zelfbesturende Landschappen. In the era of independence called the name Swapraja. Ngayogyakarta Hadiningrat Sultanate established since 1755 was founded by Prince Mangkubumi who later titled Sultan Hamengku Buwono I. Kadipaten Pakualam, established since 1813, founded by Prince Notokusumo, (brother of Sultan Hamengku Buwono II) later titled Duke of Paku Alam I.

Both Kasultanan and Pakualaman, recognized by the Government of the Dutch East Indies as a kingdom with the right to regulate its own household. All of that is stated in the political contract. The last political contract of the Sultanate is listed in the 1941 Staatsblad. 47 and the political contract of Pakualaman in Staatsblaad 1941. 577. At the time of the Proclamation of Independence of Indonesia, Sri Sultan Hamengkubuwono IX and Sri Paku Alam VIII knocked the wire to the President of the Republic of Indonesia, stating that the Yogyakarta Sultanate and Pakualaman Region became part of the territory of the Republic of Indonesia, and merged into one unified DIY Yogyakarta. Sri Sultan Hamengku Buwono IX and Sri Paku Alam VIII as Regional Head and Deputy Regional Head are directly responsible to the President of the Republic of Indonesia. The rule of law is:

1) Charter of the position of Sri Sultan Hamengku Buwono IX and Sri Paku Alam VIII dated 19 August 1945 from the President of the Republic of Indonesia.

2) The mandate of Sri Sultan Hamengku Buwono IX and the Mandate of Sri Paku Alam VIII dated September 5, 1945 (which was made separately separate).

3) The Mandate of Sri Sultan Hamengku Buwono IX and Sri Paku Alam VIII dated 30 October 1945 (made together in one manuscript). 


\section{B. Establishment of the Special Territory of Yogyakarta as a special autonomous region}

At this time Kraton Yogyakarta led by Sri Sultan Hamengku Buwono X and Puro Pakualaman by Sri Paduka Paku Alam IX. Both play a decisive role in preserving Javanese cultural values and customs and are a unifying community of Yogyakarta. On the basis of article 18 of the 1945 Constitution, the People's Legislative Assembly of Province of Daerah Istimewa Jogjakarta wishes that the status of a Special Region for the First Level Region shall remain sustainable with due regard to the history of the formation and development of its duly respected Regional Government.

Article 18 of the 1945 Constitution states that "the division of the Indonesian Territory over large and small areas, with the form of its administration established by law with regard to and remembering the basis of deliberations in the system of State Government and the rights of origin in the Territories Special ". As an Autonomous Region at the Provincial level, Daerah Istimewa Yogyakarta was established by Law No.3 of 1950, in accordance with the intent of article 18 of the 1945 Constitution. Mentioned that the Special Region of Yogyakarta is covering the former Region / Kasultanan Yogyakarta and Pakualaman Region. In the journey to become a special autonomous region, Yogyakarta get criticism and debate that can only be solved by way of study and input from the public. This led to changes in the Law for the privilege of Yogyakarta, including:

1) In the formulation of Act number I of 1957 on the subject principal of local government, 4 main issues that are debated broken into the following articles of the law:

a. The system of real autonomy, namely the opportunity for the regions to fulfill their duties fully in accordance with their talents and abilities in order to expand widely. 
b. The level of the regions set out in the law is the opinion of the government that is two levels of autonomous regions and if it needs three levels.

c. The head of the region must gain confidence and be in charge of the people's trust.

d. The law imposes oversight to the interior minister for

e. The law imposes oversight to the minister of interior for the first-level regions and to the upper-level DPD for other regions by suspending or canceling regulations and decisions of DPRD or DPD that are not in accordance or contrary to higher laws or regulations public interest. With Law No. 1/1957 this contradiction between the central government that wants the regions can be tightly controlled with the institutions and bureaucracies of government and regions that want the broadest autonomy compromised by the government and the House of Representatives.

2) After Law No. 1/1957, it turns out the problem reemerged, the start of the Indonesian democracy party in the period 1999 to 2009 still makes people wonder about the determination of the governor and vice governor of Yogyakarta Special Region. In the future, whether it will be replaced or given full power in accordance with the rules set in the 1945 Constitution. The struggle of the people of Yogyakarta in guarding its privileges as the mandate of the Sept. 5, 1945 from Sultan Hamengku Buwono IX and Duke of Paku Alam VIII, which states that Ngayogyakarto Sultanate Hadiningrat became part of NKRI, is a struggle that cannot be completed at the stage of the ratification of UU DIY only. Then in 2012 it was established Act Number 3 / of 2012 on the privileges of Yogyakarta which is divided into 3 main subject areas are:

a. Stipulation of Governor and Deputy Governor of Special Region of Yogyakarta, Charge of Governor 
and Deputy Governor of DIY agreed through determination of the respective Sultan and Pakualam registered as Governor and Vice Governor of DIY.

3) The source and mechanism of the distribution of privileges of Yogyakarta comes from APBN and also concerns the needs of the government of Yogyakarta, the implementation process is carried out through transfer to the region.

4) Implementation of privileges in the field of land privileges conducted with the provisions of Sultan and Pakualaman ground is a legal entity subject rights.

\section{The Impact of Special Region for Yogyakarta in the Local Autonomy Law Context}

Regional autonomy forms in the Special Territory of Yogyakarta in doing an action, of course there is always a result that is done. In this sub-chapter, will be discussed about the positive and negative impacts in the implementation. The positive impact felt is that with regional autonomy the local government of Yogyakarta will have the opportunity to present local identity in the community. Reduced authority and central government control get high response from local government in facing problems that are in its own region. Even more funds are earned than those obtained through bureaucratic channels from the central government. The funding allows local governments to encourage regional development and to build cultural and cultural tourism programs in Yogyakarta. By conducting regional autonomy, government policies will be more targeted, it is because the regional government tends better understand the situation and the situation of the region, and the potential that exists in the region than the central government.

The negative impact of regional autonomy is the existence of opportunities for the local authorities to take actions that could harm the State and the people such as 
corruption, collusion, and nepotism. In addition, sometimes there are regional policies that are inconsistent with the constitution of the State which can lead to conflict between regions with neighboring regions, or even regions with the State, such as examples of implementation of the AntiPornography Act at the regional level. This is because with the system of regional autonomy the central government will be more difficult to oversee the running of the government in the region, in addition because it is with the system of regional autonomy makes the role of central government is not so meaningful. Regional autonomy also creates an inter-regional rivalry that can sometimes lead to disunity. For example, if an area is conducting tourism promotion, then other regions will follow to do the same as if there arise business competition between regions. In addition, regional autonomy makes economic gaps far too far between regions. Rich areas will be more incentive to do development while less income areas will remain so-so alone without any development. This is very worrying because it violates Pancasila's fifth precept, which is "Social Justice for All Indonesians."

\section{RESULT AND DISCUSSION}

Daerah Istimewa Yogyakarta is a province based on Ngayogyakarta Hadiningrat Sultanate and Kadipaten Pakualaman. In addition, there were also former Surakarta Hadiningrat and Praja Mangkunagaran former Surakarta Hadunds previously enclaves in Yogyakarta. Meanwhile, the Special Territory of Yogyakarta is a province with special status or special autonomy. This status is a legacy of the preindependence era. The Sultanate of Yogyakarta as well as the Paku Alaman Duchy, as the origin or origin of DIY, has the status of "Vasal Kingdom / State / Dependent state" in colonial rule ranging from VOC, Indies (United Kingdom), Netherlands Indies (Kingdom of the Netherlands), and the last of Japan's XVI Army (Imperial Japanese) Army. Daerah Istimewa Yogyakarta, which is considered to use the 
monarchy system because the election of Regional Head / Governor conducted by hereditary in the absence of direct election like other Provinces in general is still contain the values of democracy. Yogyakarta Special Region can be said far from the word monarchy it is seen from the participation of the people in the government, and also the election of the Governor is done for generations it is on the will of the community because the element of tradition from the ancestors is still very thick in Yogyakarta, so that the Government must respect and acknowledge the existence of such privileges which is shown by forming / drafting a law that clearly regulates the privileges of Yogyakarta which have been decided.

\section{DECLARATION OF CONFLICTING INTERESTS}

The Author declares that there is no potential conflict of interest in the research, authorship, and/or publication of this article.

\section{FUNDING}

None

\section{ACKNOWLEDGEMENT}

None

\section{REFERENCES}

Bahar, S. et. al., ed (1993). Minutes of BPUPKI-PPKI Meeting 29 May 1945-19 August 1945. Second edition. Jakarta: State Secretariat RI.

Darwan, P. (2002). Pemberantasan Tindak Pidana Korupsi. Bandung: Aditya Bakti.

Law Number 13 of 2012 on the Privileges of Yogyakarta.

Poerwokoeoemo, S. (1984). Special Region of Yogyakarta. Yogyakarta: Gadjah Mada University Press.

Selosoemardjan, S. ed. (1962). Social Changes in Jogjakarta.

New York: Cornell University Press.

Wahyukismoyo, H. (2004). Privileges jogja vs Democratization.

Bayu Indra Grafika, Yogyakarta. 


\section{A healthy democracy requires a decent society; it requires that we are honorable, generous, tolerant and respectful.}

Charles W. Pickering 